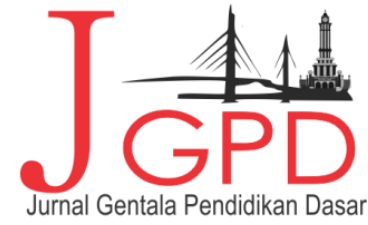

Research Article

\title{
Hubungan Gaya Mengajar Guru Dengan Keaktifan Belajar Siswa Sekolah Dasar
}

\author{
Emosda $^{1}$, Eka Putri Anggraini ${ }^{2}$
}

${ }^{1)}$ Bimbingan Konseling FKIP Universitas Jambi ${ }^{2)}$ PGSD FKIP Universitas Jambi, Jambi Indonesia

\section{Article Information}

Reviewed : Feb 20, 2018

Revised : April 10, 2018

Available Online : Jun 29, 2018

\section{Keyword}

teacher teaching style and

learning activeness

\section{Corespondence}

e-mail : emosda56@yahoo.co.id

\section{ABSTRACT}

The purpose of this study was to determine the relationship between teacher teaching styles and learning activeness of students of Class V SD Negeri 51 / IV Jambi City. This type of research is (correlational) research, namely "research intended to determine whether there is a relationship between two or more variables or the relationship between independent variables and dependent variables" The study was conducted in class Va and Vb of SD Negeri 51 / IV Jambi City, Jalan Raja Yamin Rt 27/08 Selamat Kelurahan Telanaipura District Jambi City. When research is planned for June 2015. Based on the results of the test research from the normality test for teacher teaching style data Lo (0.0903) <Ltabel (0.1153), while the student learning activeness data obtained Lo (0.1014) <Label (0.1153). The variance homogeneity test used is the $F$ test which is said to be homogeneous if $\mathrm{F}$ count $<\mathrm{F}$ table, based on data analysis obtained $F$ count $(2,006)<F$ table $(3.15)$ then based on the results of the analysis it can be concluded that the data is homogeneous variance. By using the formula (n-2) 59-2 $=57$ at $\alpha=0.05$, then with $\mathrm{dk} 2$,for the two-party test $\mathrm{t} 0.95=1.6720$ it is easy to see that $11.15883>1.6720$ then there is a relationship between teacher teaching style and learning activeness of fifth grade students of SD N 51 / IV Jambi City.

\section{DOI : https://doi.org/10.22437/gentala.v3i1.6766}

\section{PENDAHULUAN}

Globalisasi memberikan pengaruh pada percepatan pembangunan nasional. Perubahan-perubahan yang terjadi dalam pembangunan sebagai akibat dari kemajuan teknologi selalu menuntut pengembangan, perluasan pengetahuan dan ketrampilan yang menyadarkan manusia untuk menyiapkan diri sebaikbaiknya menghadapi persaingan di masa yang akan datang.

Pendidikan pada dasarnya merupakan proses untuk membantu manusia dalam mengembangkan potensi dirinya sehingga mampu menghadapi setiap perubahan yang terjadi. Dalam rangka pembangunan manusia Indonesia seutuhnya, pembangunan di bidang pendidikan merupakan sarana dan wahana yang sangat baik dalam pembinaan sumber daya 


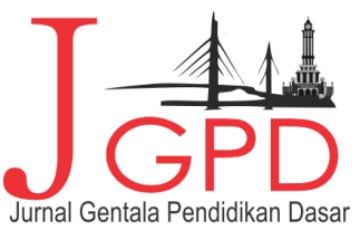

JURNAL geNTALA PENDIDIKAN DASAR Vol.3 No. I June 2018 Page 92-IID

P-ISSN : 2614-7092, E-ISSN : 2621-96il

Available Online at: http://online-journal.unja.ac.id/index.php/gentala email : penyunting.jurnal.g-pgsd逐unja.ac.id

insani. Oleh karena itu, pendidikan perlu mendapat perhatian dari negara melalui elemennya yakni pemerintah, masyarakat dan pengelola pendidikan khususnya.

Sejalan dengan perkembangan masyarakat dewasa ini, pendidikan banyak menghadapi berbagai tantangan dan hambatan. Salah satu tantangan yang cukup menarik adalah yang berkenaan dengan peningkatan mutu pendidikan. Banyak faktor yang dapat mempengaruhi mutu pendidikan yakni pendidik, sarana dan prasarana, pengelolaan, penilaian, dan sebagainya.

Dalam UU No. 20 Tahun 2003 tentang Sistem Pendidikan Nasional, mengamanatkan adanya peningkatan mutu pendidikan pada setiap jenjang. Peningkatan mutu pendidikan dapat dicapai melalui berbagai cara, antara lain melalui peningkatan kualitas pendidikan dan tenaga kependidikan lainnya, pelatihan dan pendidikan, atau dengan memberikan kesempatan untuk menyelesaikan masalah-masalah pembelajaran dan non pembelajaran secara profesional secara terkendali.

Mengajar bukanlah semata-mata persoalan memberikan ceramah pada siswa tentang materi yang akan diajarkan. Dalam mengajar dibutuhkan strategi mengajar agar para siswa mudah menerima pelajaran dan sulit untuk melupakan apa yang telah diajarkan oleh guru. Guru harus mempersiapkan dan merancang apa yang akan disampaikan dan strategi apa yang tepat agar siswa lebih menerima pelajaran. Agar perencanaan pembelajaran efektif, maka perencanaan haruslah berpegang pada pemahaman guru akan kelas serta materi ajar yang akan disampaikan.

Selain perencanaan pembelajaran, dalam mencapai memiiki pembelajaran yang efektif guru harus memiliki ketrampilan untuk menyampaikan materi. Kemampuan guru menyampaikan materi ajar yang kurang memadai dapat menyebabkan kelas menjadi kurang menarik dan cenderung membosankan siswa. Suara guru yang terlalu atau kurang keras, sikap guru yang kurang tegas, pendekatan atau metode pembelajaran yang kurang tepat, maupun posisi guru saat mengajar banyak duduk dapat membawa suasana yang kurang menarik perhatian siswa.

Sementara itu, lingkungan belajar juga memberikan kontribusi akan berhasil tidaknya pengajar. Lingkungan belajar yang tidak sesuai/mendukung akan memberikan pengaruh negatif terhadap kelas, sehingga kelas menjadi tidak efektif. 


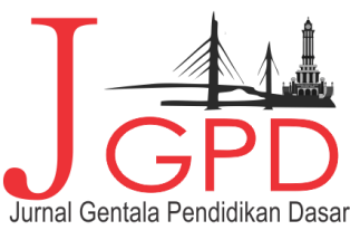

JURNAL geNTALA PENDIDIKAN DASAR Vol.3 No. I June 2018 Page 92-IID

P-ISSN : 2614-7092, E-ISSN : 2621-96il

Available Online at: http://online-journal.unja.ac.id/index.php/gentala email : penyunting.jurnal.g-pgsd迎uja.ac.id

Proses belajar mengajar juga tidak bisa dilepaskan dari alat/media yang digunakan dalam penyampaian pengajaran kepada siswa. Penggunaan medi pengajaran dimaksudkan untuk memusatkan perhatian siswa, sehingga mengefisienkan kegiatan belajar mengajar dan membatasi keterbatasan ruang dan waktu.

Pendidikan yang baik tidak bisa lepas dari komponen pendidikan yang akan menentukan berhasil atau tidaknya proses pendidikan yang dijalankan. Komponen yang dimaksud di sini adalah pendidik, peserta didik, tujuan, materi/ bahan ajar, metode, alat (media), dan evaluasi yang pasti akan menjadi pertimbangan guru untuk menentukan perencanaan pengajaran yang tepat.

Guru perlu belajar setiap saat dalam arti belajar menjadikan proses belajar mengajar menjadi semakin efektif. Salah satu hal paling strategis dilakukan guru adalah melakukan penelitian, sehingga dapat menciptakan proses pembelajaran yang PAIKEM yaitu Pembelajaran Aktif, Inovatif, Kreatif, Efektif, dan Menyenangkan.

Untuk melihat terwujudnya keaktifan siswa dalam proses belajar mengajar terdapat beberapa indikator cara belajar siswa aktif. Melalui indikator cara belajar siswa aktif dapat dilihat tingkah laku mana yang muncul dalam suatu proses belajar mengajar.

Indikator tersebut yaitu: “(1) keinginan, keberanian menampilkan minat, kebutuhan dan permasalahannya; (2) keinginan dan keberanian serta kesempatan untuk berpartisipasi dalam kegiatan persiapan, proses dan kelanjutan belajar; (3) penampilan berbagai usaha/kekreatifan belajar mengajar sampai mencapai keberhasilannya; dan (4) kebebasan melakukan hal tersebut tanpa tekanan guru/ pihak lainnya" (Supriyono, 2004: 207-208).

Keaktifan siswa tampak dalam kegiatan, antara lain: “(1) berbuat sesuatu untuk memahami materi pelajaran dengan penuh keyakinan; (2) mempelajari, mengalami dan menemukan sendiri bagaimana memperoleh situasi pengetahuan; (3) merasakan sendiri bagaimana tugas-tugas yang diberikan oleh guru kepadanya; (4) belajar dalam kelompok; (5) mencoba sendiri konsep-konsep tertentu; dan (6) mengkomunikasikan hasil pikiran, penemuan, dan penghayatan nilai-nilai secara lisan atau penampilan" (Suryosubroto, 2002: 71-72).

Siswa dikatakan aktif dalam pembelajaran bila terdapat ciri-ciri sebagai berikut (Suryosubroto, 2002: 71): 1. Siswa berbuat sesuatu untuk memahami materi pelajaran 2. 


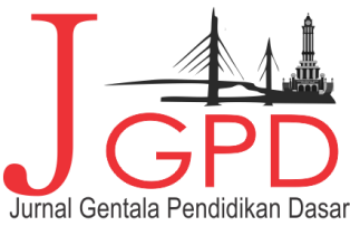

JURNAL geNTALA PENDIDIKAN DASAR Vol.3 No. I June 2018 Page 92-IID

P-ISSN : 2614-7092, E-ISSN : 2621-96il

Available Online at: http://online-journal.unja.ac.id/index.php/gentala email : penyunting.jurnal.g-pgsd@迆ja.ac.id

Pengetahuan dipelajari, dialami dan ditemukan oleh siswa 3. Mencobakan sendiri konsepkonsep 4. Siswa mengkomunikasikan hasil pikirannya.

Berdasarkan ciri-ciri keaktifan siswa yang telah disebutkan oleh 3 ahli maka indikator keaktifan siswa dapat disimpulkan sebagai berikut: (1) keberanian untuk mengungkapkan pikiran, perasaan, keinginan dan kemauannya serta menampilkan berbagai usaha dalam kegiatan belajar; (2) berpartisipasi dalam kegiatan persiapan, proses dan kelanjutan belajar serta mengkomunikasikan hasil belajar; (3) menampilkan berbagai usaha belajar untuk mencapai keberhasilan (kreativitas belajar); dan (4) mempelajari, mengalami dan menemukan sendiri pengetahuan yang diperoleh.

Berdasarkan pendapat diatas siswa kelas V SD Negeri 51/IV Kota Jambi masih banyak siswa yang belum aktif dalam belajar, dimana siswa banyak diam saat belajar dan pembelajaran diruangan, interaksi dengan guru masih kurang, mendapatkan permasalahan tersebut perlu diketahuinya ada atau tidaknya keterkaitan dengan gaya mengajar guru tersebut.

Menurut M. Saputra (2000: 21) "gaya mengajar merupakan interaksi yang dilakukan guru dengan siswa dalam proses belajar mengajar agar materi yang disajikan dapat diserap oleh siswa". Dari pengertian tersebut dapat diartikan bahwa, gaya mengajar merupakan keputusan berupa tindakan interaksi mengajar yang dianggap sesuai, bertujuan materi tersampaikan kepada siswa.

Menurut Sudjana (2004:61) keaktifan siswa dapat dilihat dalam hal: a) Turut serta dalam melaksanakan tugas belajarnya b) Terlibat dalam pemecahan masalah c) Bertanya kepada siswa lain/ kepada guru apabila tidak memahami persoalan yang dihadapinya d) Berusaha mencari berbagai informasi yang diperoleh untuk pemecahan masalah e) Melaksanakan diskusi kelompok f) Menilai kemampuan dirinya dan hasil yang diperolehnya g) Kesempatan menggunakan/menerapkan apa yang diperolehnya dalam menyelesaikan tugas / persoalan yang dihadapinya h) Kesempatan menggunakan/menerapkan apa yang diperolehnya dalam menyelesaikan tugas / persoalan yang dihadapinya

Dari ciri - ciri keaktifan menurut Sudjana di atas, maka dapat diambil delapan indikator : 
1) Turut serta dalam melaksanakan tugas belajarnya. Maksud dari indikator ini adalah siswa ikut serta dalam proses pembelajaran misalnya siswa mendengarkan, memperhatikan, mencatat dan mengerjakan soal dan sebagainya.

2) Terlibat dalam pemecahan masalah Maksud dari indikator tersebut adalah ikut aktif dalam menyelesaikan masalah yang sedang dibahas dalam kelas, misalnya ketika guru memberi masalah/ soal siswa ikut membahas

3) Bertanya kepada siswa lain/ kepada guru apabila tidak memahami persoalan yang dihadapinya Maksud dari indikator tersebut adalah jika tidak memahami materi/ penjelasan dari guru hendaknya siswa melontarkan pertanyaan, baik pada guru/siswa lain.

4) Berusaha mencari berbagai informasi yang diperoleh untuk pemecahan masalah Maksud indikator tersebut adalah berusaha mencari informasi /cara yang bisa digunakan dalam menyelesaikan suatu masalah /soal. Yaitu siswa mencari informasi dari buku.

5) Melaksanakan diskusi kelompok. Maksud dari indikator tersebut adalah melakukan kerja sama dengan teman diskusi untuk menyelesaikan masalah/ soal.

6) Menilai kemampuan dirinya dan hasil yang diperolehnya Maksud dari indikator tersebut adalah menilai kemampuan dirinya yaitu dengan mencoba mengerjakan soal setelah guru menerangkan materi

7) Melatih diri dalam memecahkan soal/ masalah, yaitu siswa dapat mengerjakan soal/ permasalahan, dengan mengerjakan LKS. Maksud dari indikator tersebut adalah dapat menyelesaikan soal/ masalah yang pernah diajarkan/ dibahas bersama. Yaitu siswa mengerjakan LKS.

8) Kesempatan menggunakan/ menerapkan apa yang diperolehnya dalam menyelesaikan tugas / persoalan yang dihadapinya

Pembelajaran Menurut E. Mulyasa (2002:32), “pembelajaran dikatakan berhasil dan berkualitas apabila seluruhnya atau setidak-tidaknya sebagian besar peserta didik terlibat secara aktif, baik fisik, mental maupun sosial dalam proses pembelajaran”.

Hamalik (2002:27), menyatakan bahwa "dalam proses pendidikan di sekolah, tugas utama guru adalah mengajar sedangkan tugas utama setiap siswa adalah belajar. Belajar merupakan suatu proses, suatu kegiatan, dan bukan suatu hasil atau tujuan." 


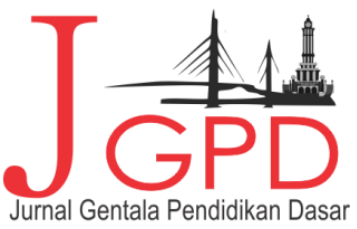

JURNAL gENTALA PENDIDIKAN DASAR Vol.3 o. I June 20I8 Page 92-1I0

P-ISSN : 2614-7092, E-ISSN : 262I-9611

Available Online at: http://online-journal.unja.ac.id/index.php/gentala email : penyunting.jurnal.g-pgsd@unja.ac.id

Menurut Sardiman (2006:47) "belajar mengacu pada kegiatan siswa dan mengajar mengacu pada kegiatan guru. Mengajar pada dasarnya merupakan suatu usaha untuk menciptakan kondisi atau sistem lingkungan yang mendukung dan memungkinkan untuk berlangsungnya proses pembelajaran". Sanjaya (2004:87) "menyampaikan bahwa keterkaitan antara belajar dan mengajar itulah yang disebut dengan pembelajaran".

Aktivitas dalam suatu pembelajaran bukan hanya siswa yang aktif belajar tetapi di lain pihak, guru juga harus mengorganisasi suatu kondisi yang dapat mengaktifkan siswa dalam belajar.

Guru sebagai fasilitator dan pembimbing harus memiliki sepuluh keterampilan khusus yang harus dimiliki oleh seorang guru, yaitu: 1) Ketrampilan membuka pelajaran, 2) Ketrampilan memberi motivasi, 3) Ketrampilan bertanya, 4) Ketrampilan menerangkan, 5) Ketrampilan mendayagunakan media, 6) Ketrampilan menggunakan metode yang tepat, 7) Ketrampilan mengadakan interaksi, 8) Ketrampilan penampilan verbal dan non verbal, 9) Ketrampilan penjajagan/assesment, dan 10) Ketrampilan menutup pelajaran. (http://ekagurunesama,blogspot.com/2010/03-/10-keterampilan-guru.html, diakses tanggal 21/3/2015).

Dari uraian tersebut di atas dapat dsimpulkan bahwa keaktifan siswa dalam pembelajaran sangat penting. Belajar di kelas tidak hanya sekedar mendengarkan dan menerima materi dari guru, namun siswa harus aktif dan guru dapat mengaktifkan. Tugas guru sebagai fasilitator dan pembimbing adalah memberikan bantuan dan arahan berdasarkan sepuluh keterampilan seorang guru di atas.

Aktivitas terbaik oleh siswa ialah ketika siswa dapat membaca, mendengar, melihat, mengucap dan melakukan tentang materi yang sedang dipelajarinya. Sehingga siswa benarbenar dapat mengingat materi yang diterimanya.

Berdasarkan pendapat di atas peneliti ingin melakukan penelitian dengan judul "Hubungan Gaya Mengajar Guru Dengan Keaktifan belajar Siswa Kelas VSD Negeri 51/IVKota Jambi”.

Mengingat luasnya ruang lingkup penelitian dan keterbatasan yang peneliti miliki, maka dalam penelitian ini peneliti melakukan fokus penelitian yaitu Gaya mengajar yang dimaksud adalah frofil guru dalam proses penyampaian materi pelajaran. Guru yang dimaksud adalah Guru Kelas V SD Negeri 51/IVKota Jambi. Keaktifan belajar Siswa ialah 


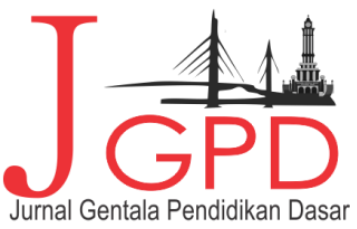

JURNAL gENTALA PENDIDIKAN DASAR Vol.3 o. I June 20I8 Page 92-1I0

P-ISSN : 2614-7092, E-ISSN : 262I-9611

Available Online at: http://unline-journal.unja.ac.id/index.php/gentala

email : penyunting.jurnal.g-pgsd@unja.ac.id

kegiatan siswa dalam proses belajar di Kelas. Siswa yang dimaksud adalah siswa Guru Kelas V SD Negeri 51/IVKota Jambi.

Sesuai dengan fokus penelitian, maka dalam penelitian ini sebagai pertanyaan yang diajukan adalah "Bagaimana kualitas gaya mengajar guru di kelas V SD Negeri 51/IV Kota Jambi? dan "Bagaimana kualitas Keaktifan belajar Siswa di kelas V SD Negeri 51/IV Kota Jambi?"

Sejalan dengan pertanyaan penelitian, maka sebagai tujuan dari penelitian ini adalah untuk mengetahui kualitas gaya mengajar guru di kelas V SD Negeri 51/IV Kota Jambi dan untuk mengetahui kualitas Keaktifan belajar Siswa di kelas V SD Negeri 51/IV Kota Jambi.

\section{METODE PENELITIAN}

\section{Jenis Penelitian}

Jenis penelitian ini merupakan penelitian (korelasional) yaitu "penelitian yang dimaksudkan untuk mengetahui ada tidaknya hubungan antara dua variabel atau lebih atau hubungan antara variabel bebas dengan variabel terikat" Iskandar (2008:63).

Menurut Arikunto, (2006: 326) "dengan teknik korelasi seorang peneliti dapat mengetahui hubungan variasi dalam sebuah variable dengan variasi yang lain". Di dalam penelitian korelasional menerangkan sejauh mana dua atau lebih variable yang berkorelasi.

\section{Jenis dan Sumber Data}

\section{Data Primer}

Data primer adalah data yang diperoleh langsung dari sumbernya tanpa ada perantara. Data primer yang penulis maksudkan dalam penelitian ini adalah bersumber dari observasi, tes, dan angket. Data-data tersebut adalah tentang gaya mengajar guru dan keaktifan belajar siswa di kelas sehingga akan terlihat oleh oleh peneliti ada tidaknya hubungan gaya mengajar guru dengan keaktifan belajar siswa kelas V SD N 51/IV Kota Jambi.

\section{Data Sekunder}




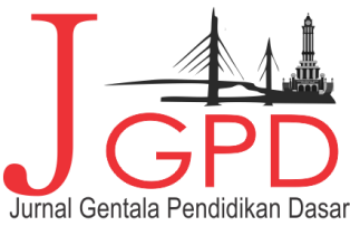

JURNAL gENTALA PENDIDIKAN DASAR Vol.3 o. I June 20I8 Page 92-1I0

P-ISSN : 2614-7092, E-ISSN : 262I-9611

Available Dnline at: http://online-journal.unja.ac.id/index.php/gentala email : penyunting.jurnal.g-pgsd@unja.ac.id

Data sekunder adalah data yang diambil secara tidak langsung atau bersumber dari tangan kedua. Data sekunder dalam penelitian ini adalah data yang terkait dengan penelitian dan diambil dari dokumentasi siswa kelas V SD N 51/IV Kota Jambi. Data sekunder lainnya merupakan studi atau kajian pustaka yang merupakan teori-teori yang terkait dengan penelitian ataupun judul penelitian.

\section{Tempat Penelitian dan Informan Penelitian}

Penelitian dilaksanakan di kelas Va dan Vb SD Negeri 51/IV Kota Jambi, jalan Raja Yamin Rt 27/08 Kelurahan Selamat Kecamatan Telanaipura Kota jambi. Waktu penelitian dilaksanakan pada bulan Juni 2015.

Penelitian ini, yang bertindak selaku informan dari melalui kegiatan wawancara adalah guru dan kelas Va serta Vb SD Negeri 51/IV Kota Jambi.

\section{Instrumen Penelitian}

Instrumen penelitian adalah "alat atau fasilitas yang digunakan peneliti dalam mengumpulkan data agar pekerjannya lebih mudah dan hasilnya lebih baik, dalam arti lebih cermat, lengkap dan sistematis sehingga lebih mudah diolah.

Variasi jenis instrumen penelitian adalah, angket, ceklis (check-list), atau daftar centang, pedoman wawancara, pedoman pengamatan”. (Arikunto, 2006:160).

Instrumen penelitian ini menggunakan angket tertutup dalam bentuk skala sikap dari Linkert, berupa pertanyaan atau pernyataan yang jawabannya berbentuk skala deskriptif. Angket tertutup untuk mengungkap data tentang variabel bebas dan variable terikat, data dari variabel bebas dan variabel diambil dari pertanyaa angket yang diisikan ole siswa.

Alternatif jawaban menggunakan skala linkert dengan lima alternatif jawaban, misalnya selalu (SL), sering (SR), Kadang-kadang (KK), jarang (JR), dan Tidak Pernah (TP). Sskor untuk jawaban dari pertanyaan/pernyataan positif adalah $\mathrm{SL}=5, \mathrm{SR}=4, \mathrm{KK}=3$, $\mathrm{JR}=2$, dan $\mathrm{TP}=1$.

\section{Teknik Pengumpulan Data}




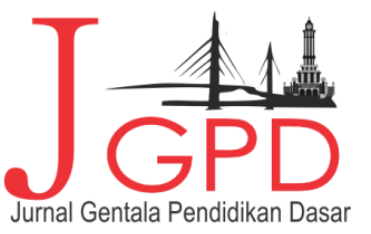

JURNAL GeNTALA PENDIDIKAN DASAR Vol.3 No. I June 2018 Page 92-1I0

P-ISSN : 2614-7092, E-ISSN : 262I-S6II

Available Online at: http://online-journal.unja.ac.id/index.php/gentala email : penyunting.jurnal.g-pgsd@unja.ac.id

Teknik mengumpulkan data menggunakan angket tertutup dalam bentuk skala sikap dari Linkert, berupa pertanyaan atau pernyataan yang jawabannya berbentuk skala deskriptif. Kisi-kisi Angket ada pada tabel 1 berikut.

Tabel 1 Kisi kisi Instrumen Angket Gaya Mengajar Guru.

\begin{tabular}{|c|c|c|c|c|}
\hline Variabel & Dimensi & Indikator & Deskriptor & $\begin{array}{l}\text { Item } \\
\text { Soal }\end{array}$ \\
\hline \multirow{19}{*}{$\begin{array}{l}\text { Gaya } \\
\text { mengajar } \\
\text { guru }\end{array}$} & \multirow{12}{*}{$\begin{array}{l}\text { Gaya } \\
\text { mengajar guru } \\
\text { yang positif }\end{array}$} & \multirow{2}{*}{$\begin{array}{l}\text { 1. Menguasai } \\
\text { materi pelajaran } \\
\text { secara } \\
\text { mendalam }\end{array}$} & $\begin{array}{l}\text { 1.1. Menguasai materi yang akan } \\
\text { disampaikan }\end{array}$ & 1,2 \\
\hline & & & $\begin{array}{l}\text { 1.2. Menjelaskan materi tanpa } \\
\text { melihat buku }\end{array}$ & 3,4 \\
\hline & & \multirow[t]{2}{*}{$\begin{array}{l}\text { 2. Mempunyai } \\
\text { wawasan luas }\end{array}$} & $\begin{array}{l}2.1 \text { mengkaitkan materi dengan } \\
\text { keadaan sebenarnya }\end{array}$ & 5,6 \\
\hline & & & $\begin{array}{l}2.2 \text { menjelaskan pelajaran dengan } \\
\text { baik }\end{array}$ & 7,8 \\
\hline & & \multirow[t]{2}{*}{ 3. Komunikatif } & $\begin{array}{l}\text { 3.1 Selalu komunikasi dengan } \\
\text { siswa }\end{array}$ & 9,10 \\
\hline & & & $\begin{array}{l}3.2 \text { selalu mengajak siswa } \\
\text { berinteraksi }\end{array}$ & 11,12 \\
\hline & & \multirow{2}{*}{$\begin{array}{ll}\text { 4. } & \text { Mempunyai } \\
\text { Variasi } \\
\text { Pendekatan }\end{array}$} & $\begin{array}{l}4.1 \text { guru memberikan metode } \\
\text { mengajar baru }\end{array}$ & 13,14 \\
\hline & & & 4.2 memberikan variasi- & 15,16 \\
\hline & & \multirow{2}{*}{$\begin{array}{ll}5 . & \text { Tidak terlalu } \\
\text { menekan dan } \\
\text { memaksa }\end{array}$} & $\begin{array}{l}5.1 \text { dapat menjelaskan materi yang } \\
\text { belum dikuasai siswa }\end{array}$ & 17,18 \\
\hline & & & $\begin{array}{l}5.2 \text { menjelaskan materi dengan } \\
\text { baik }\end{array}$ & 19,20 \\
\hline & & \multirow[t]{2}{*}{$\begin{array}{l}\text { 6. Humoris, tapi } \\
\text { serius }\end{array}$} & $\begin{array}{l}6.1 \text { menyampaikan materi dengan } \\
\text { humoris }\end{array}$ & 21,22 \\
\hline & & & 6.2 membuat siswa tidak jenuh & 23,24 \\
\hline & \multirow[t]{7}{*}{$\begin{array}{l}\text { Gaya } \\
\text { mengajar guru } \\
\text { yang negative }\end{array}$} & \multirow[t]{2}{*}{$\begin{array}{l}\text { 1. Duduk diatas } \\
\text { meja ketika } \\
\text { mengajar }\end{array}$} & $\begin{array}{l}\text { 1.1 menyampaikan materi sampai } \\
\text { sambil duduk di meja siswa }\end{array}$ & 25,26 \\
\hline & & & $\begin{array}{l}1.2 \text { menyampaikan materi sambil } \\
\text { duduk di meja guru }\end{array}$ & 27,28 \\
\hline & & $\begin{array}{l}\text { 2. Tidur sewaktu } \\
\text { mengajar }\end{array}$ & $\begin{array}{l}2.1 \text { tidur disaat jam pelajaran } \\
\text { berlangsung }\end{array}$ & 29,30 \\
\hline & & $\begin{array}{l}\text { 3. Sering bolos } \\
\text { mengajar }\end{array}$ & $\begin{array}{l}3.1 \text { guru pulang mengajar saat jam } \\
\text { belajar belum selesai }\end{array}$ & 31,32 \\
\hline & & \multirow[t]{2}{*}{ 4. Tidak disiplin } & 4.1 guru selalu terlambat mengajar & 33,34 \\
\hline & & & $\begin{array}{l}4.2 \text { guru mengakhiri pelajaran saat } \\
\text { jam belajar belum selesai }\end{array}$ & 35,36 \\
\hline & & Berpakaian & 5.1 berpakaian tidak rapi saat & 37,38 \\
\hline
\end{tabular}




\begin{tabular}{llll} 
& tidak rapi & mengajar & \\
\hline 6. & Suka memberi & $\begin{array}{l}\text { 6.1 setiap belajar selalu } \\
\text { PR tanpa } \\
\text { memberikan pekerjaan rumah (PR) }\end{array}$ & 39 \\
\cline { 3 - 3 } & $\begin{array}{l}\text { 6.2 Memberikan tugas tanpa } \\
\text { mengoreksi }\end{array}$ & 40
\end{tabular}

(Hamalik, 2002:5,6)

Tabel 2 Kisi kisi Instrumen Anket Keaktifan Belajar Siswa.

\begin{tabular}{|c|c|c|c|}
\hline Variabel & Indikator & Deskripsi & Item soal \\
\hline \multirow[t]{12}{*}{ Keaktifan belajar siswa } & \multirow[t]{2}{*}{$\begin{array}{l}\text { Rasa ingin tahu yang } \\
\text { tinggi }\end{array}$} & $\begin{array}{l}\text { 1. Keingintahuan akan hal baru } \\
\text { sangat besar }\end{array}$ & $1,2,3$ \\
\hline & & $\begin{array}{l}\text { 2. Dapat mencari jawaban } \\
\text { Sendiri }\end{array}$ & 4,5 \\
\hline & \multirow[t]{2}{*}{ Pantang menyerah. } & $\begin{array}{l}\text { 1.Akan selalu terus melakukan } \\
\text { pencarian untuk menemukan } \\
\text { jawaban. }\end{array}$ & 6,7 \\
\hline & & $\begin{array}{l}\text { 2. Mencari tahu permasalahan } \\
\text { yang terjadi }\end{array}$ & 8,9 \\
\hline & \multirow[t]{2}{*}{$\begin{array}{l}\text { Berani mengambil } \\
\text { resiko }\end{array}$} & $\begin{array}{l}\text { 1.Tidakmudah menyerah } \\
\text { dengan berbagai resiko yang } \\
\text { akan dihadapinya. }\end{array}$ & 10,11 \\
\hline & & $\begin{array}{l}\text { 2. Melaksanakan tugas dengan } \\
\text { aktif }\end{array}$ & 12,13 \\
\hline & \multirow[t]{4}{*}{$\begin{array}{l}\text { Ingin menvari } \\
\text { pengalaman- } \\
\text { pengalaman baru }\end{array}$} & $\begin{array}{l}\text { 1. Belum merasa puas terhadap } \\
\text { apa yang telah mereka capai. }\end{array}$ & 14,15 \\
\hline & & $\begin{array}{l}\text { 2. Mengerjakan tugas tanpa } \\
\text { mempelajarai sebelumnya }\end{array}$ & 16,17 \\
\hline & & $\begin{array}{l}\text { 1. akan selalu optimis dengan apa yang } \\
\text { telah mereka kerjakan }\end{array}$ & 18,19 \\
\hline & & $\begin{array}{l}\text { 2. selalu optimis dengan pendapat yang } \\
\text { diucapkan }\end{array}$ & 20,21 \\
\hline & \multirow[t]{2}{*}{ Proaktif } & $\begin{array}{l}\text { 1. selalu mempunyai kesadaran yang } \\
\text { tinggi }\end{array}$ & 22,23 \\
\hline & & $\begin{array}{l}\text { 2. selalu bertanya jika tidak mengerti } \\
\text { dengan materi pelajaran }\end{array}$ & 24,25 \\
\hline
\end{tabular}

Munandar(1999: 51)

\section{Dokumentasi}

Dokumen administratif berupa pengumpulan dokumen-dokumen administratif tentang guru, siswa, dan sekolah serta dokumen lain yang terkait dengan penelitian. Hal ini peneliti lakukan guna meningkatkan derajat keabsahan penelitian. 


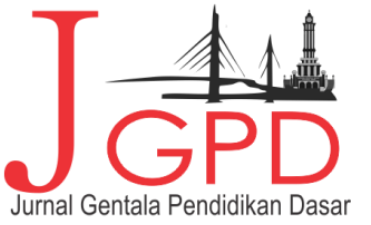

JURNAL gENTALA PENDIDIKAN DASAR Vol.3 No. I June 2018 Page 92-1I0

P-ISSN : 2614-7092, E-ISSN : 262I-S6II

Available Dnline at: http://online-journal.unja.ac.id/index.php/gentala

email : penyunting.jurnal.g-pgsd回unja.ac.id

\section{Validitas Dan Relibilitas Angket}

\section{Relibilitas}

Untuk menentukan validitas butir angket dapat digunakan rumus korelasi product moment dengan angka kasar (Arikunto 2010:213), yaitu :

$$
r_{x y}=\frac{N \sum X Y-\left(\sum X\right)\left(\sum Y\right)}{\sqrt{\left\{N\left(\sum X^{2}\right)-\left(\sum X\right)^{2}\right\}\left\{N \sum Y^{2}-\left(\sum Y\right)^{2}\right\}}}
$$

Keterangan:

$\mathrm{X}=$ Skor untuk item angket (jika betul -1 jika salah-0)

$\mathrm{Y}=$ Skor total siswa

$\mathrm{r}_{\mathrm{xy}}=$ Koefesien Korelasi

$\mathrm{N}=$ Jumlah siswa

Tabel 3 Klasifikasi harga koofisien korelasi.

\begin{tabular}{cc}
\hline Interval Korelasi & Tingkat Korelasi \\
\hline $0,80<$ rxy $\leq 1,00$ & Sangat tinggi \\
\hline $0,60<$ rxy $\leq 0,80$ & Tinggi \\
\hline $0,40<$ rxy $\leq 0,60$ & Cukup \\
\hline $0,20<$ rxy $\leq 0,40$ & Rendah \\
\hline Rxy $\leq 0,20$ & Sangat rendah \\
\hline
\end{tabular}

Angket itu dapat dikatakan valid dalam penelitian ini, jika soal-soal tersebut mempunyai koofisien korelasi cukup berkisar 0,40 - 1,00.

\section{Teknik Analisis Data}

\section{Analisis Deskriptif}

Setiap variabel akan dicari kriteria dengan menggunakan rumus:

$\frac{\mathrm{P}=\sum \mathrm{X} \times 100}{\mathrm{~N}}$

Tabel 4. Kriteria Penafsiran

\begin{tabular}{cc}
\hline $80-100$ & Sangat Baik \\
\hline $60-70$ & Baik \\
\hline
\end{tabular}




\begin{tabular}{cc}
\hline $40-59$ & Cukup \\
\hline $20-39$ & Kurang Baik \\
\hline $0-19$ & Sangat Kurang Baik.
\end{tabular}

(Sugiono, 2010: 56)

\section{Uji Normalitas}

Uji normalitas bertujuan normal atau tidak, digunakan uji (2005:466-467) sebagai berikut: untuk melihat apakah data berdistribusi Liliefors yang dikemukakan oleh Sudjana.

a. Mencari skor baku dengan rumus :

Keterangan :

$$
Z_{i}=\frac{X_{i}-\bar{X}}{S}
$$

$\mathrm{Zi}=$ Skor baku

$\mathrm{X}_{1}=$ Skor hasil

$\mathrm{X}=$ Rata-rata hasil

$\mathrm{S}=$ Simpangan baku

b. Untuk tiap bilangan baku ini, dan menggunakan daftar distribusi normal baku, kemudian dihitung peluang dengan rumus $:=\mathrm{P}\left(\mathrm{Z}<\mathrm{Z}_{\mathrm{i}}\right)$

c. Menghitung proporsi $\mathrm{Z}_{1}, \mathrm{Z}_{2}, \ldots \mathrm{Z}_{\mathrm{n}}$ yang lebih kecil atau sama dengan $\mathrm{Z}_{\mathrm{i}}$. Jika proporsi ini dinyatakan $\mathrm{S}\left(\mathrm{Z}_{\mathrm{i}}\right)$, maka,

$S(Z)$

$$
\text { banyaknya } Z_{1}, Z_{2} \ldots \ldots Z_{n} \square Z_{i}
$$

Keterangan :

$\mathrm{n}=$ Jumlah Siswa

d. Menghitung selisih $F\left(Z_{i}\right)-S\left(Z_{i}\right)$ kemudian tentukan hargamutlaknya

e. Ambil harga yang paling besar, sebutlah namanya $\mathrm{L}_{0}$

f. Membandingkan $\mathrm{L}_{0}$ dengan harga kritis $\mathrm{L}$ dalam tabel dengan $\alpha=0,05 \mathrm{Jika}_{0}<\mathrm{L}$ berarti skor hasil berdistribusi normal dan sebaliknya Jika $\mathrm{L}_{0}>\mathrm{L}$ berarti skor hasi tidak berdistribusi normall.

\section{Uji Homogenitas}




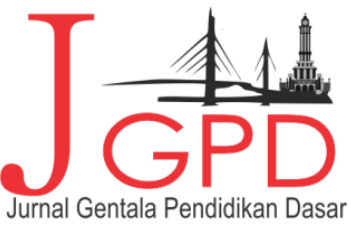

JURNAL gENTALA PENDIDIKAN DASAR Vol.3 o. I June 20I8 Page 92-1I0

P-ISSN : 2614-7092, E-ISSN : 262I-9611

Available Online at: http://online-journal.unja.ac.id/index.php/gentala

email : penyunting.jurnal.g-pgsd@unja.ac.id

Uji ini digunakan untuk melihat apakah kedua kelompok dan mempunyai varians yang homogen atau tidak. Menurut Arikunto (2006:324 ) dijelaskan rumus yang digunakan adalah sebagai berikut:

$$
\mathrm{F}=\frac{M K_{K}}{M K_{d}} \quad \text { dengan } d b_{f} \quad=d b_{k}-d b_{d}
$$

Cara untuk memnetukan kesimpulan adalah:

Tabel 5. Tabel Kesimpulan

\begin{tabular}{|c|c|c|}
\hline $\begin{array}{c}\text { Jika Fo }>\text { Ft } \\
1 \%\end{array}$ & Jika Fo > Ft $5 \%$ & $\begin{array}{c}\text { Jika Fo }<\text { Ft } \\
5 \%\end{array}$ \\
\hline $\begin{array}{l}\text { Harga Fo yang } \\
\text { diperoleh sangat } \\
\text { signifikan }\end{array}$ & $\begin{array}{l}\text { Harga Fo yang di } \\
\text { peroleh signifikan }\end{array}$ & $\begin{array}{c}\text { Harga Fo } \\
\text { yang di } \\
\text { peroleh tidak } \\
\text { signifikan }\end{array}$ \\
\hline $\begin{array}{l}\text { Ada perbedaan } \\
\text { mean yang } \\
\text { sangat } \\
\text { signifikan }\end{array}$ & $\begin{array}{l}\text { Ada perbedaan } \\
\text { mean yang } \\
\text { signifikan }\end{array}$ & $\begin{array}{c}\text { Ada } \\
\text { perbedaan } \\
\text { mean yang } \\
\text { tidak } \\
\text { signifikan }\end{array}$ \\
\hline $\begin{array}{l}\text { Hipotesis nihil } \\
\left(\mathrm{H}_{\mathrm{O}}\right) \text { di tolak }\end{array}$ & $\begin{array}{l}\text { Hipotesis nihil } \\
\left(\mathrm{H}_{\mathrm{O}}\right) \text { ditolak }\end{array}$ & $\begin{array}{c}\text { Hipotesis } \\
\text { nihil }\left(\mathrm{H}_{\mathrm{O}}\right) \\
\text { diterima }\end{array}$ \\
\hline $\begin{array}{c}\mathrm{P}<0,01 \text { atau }- \\
0,01\end{array}$ & $\mathrm{P}<0,05$ & $P>0,05$ \\
\hline
\end{tabular}

Bagi penulis secara pribadi membutuhkan cara perhitungan lain dalam uji normalitas sebagai bahan perbandingan untuk meyakinkan bahwa data yang di hitung adalah benar, sehingga di pilihlah uji normalitas dengan cara uji Harley. Dalam Iskandar (2008) dijelaskan bahwa uji Harley merupakan uji Homogenitas yang sangat sederhana karena cukup membandingkan variansi terbesar dan variansi terkecil.

$\begin{array}{cc}\mathrm{F} & \begin{array}{c}\text { Variansi } \\ (\max )=\end{array} \\ \text { terbesar } \\ \text { terkecil }\end{array}$

Hasil hitung $\mathrm{F}(\max )$ disbanding dengan $\mathrm{F}(\max )$ tabel, adapun kriteria pengujianya sebagai berikut: 


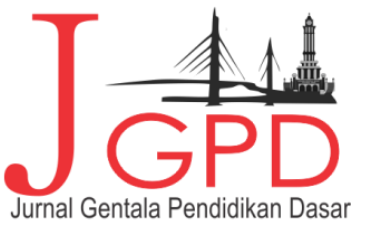

JURNAL geNTALA PENDIDIKAN DASAR Vol.3 No. I June 2018 Page 92-1ID

P-ISSN : 2614-7092, E-ISSN : 2621-96il

Available Online at: http://online-journal.unja.ac.id/index.php/gentala

email : penyunting.jurnal.g-pgsd迎uja.ac.id

Terima Ho jika $\mathrm{F}(\max )$ hitung > F $(\max )$ tabel, adapun Ho menyatakan variansi homogen, sedangkan H1 menyatakan variansi tidak homogen.

\section{Perhitungan Statistik}

Untuk mengetahui apakah terdapat hubungan antara minat belajar dengan prestasi belajar siswa digunakan rumus korelasi product moment dengan angka kasar yang dikemukakan oleh Arikunto, (2006: 170) seperti berikut: $\mathrm{X}^{2}$

$$
\mathrm{rxy}=\frac{\mathrm{N} \sum x y-\left(\sum x\right)\left(\sum y\right)}{\sqrt{\mathrm{N}\left(\sum x 2\right)-\left(( \sum y 2 ) \left\{N \sum y 2-\left(\sum y\right)^{2\}}\right.\right.}}
$$

Keterangan:

$r_{x y}=$ Koefisien korelasi suatu butir

$\mathrm{N}=$ Cacah objek

Korelasi PPM dilambangkan dengan (r) dengan ketentuan nilai r tidak lebih dari harga Apabila $r=-1$ artinya korelasi atau hubungannya negatif sempurna; $r=0$ artinya tidak ada hubungan; dan $r=1$ berarti korelasi atau hubungannya sangat kuat. Sedangkan arti harga $r$ akan dikonsultasikan dengan tabel interpretasi nilai $r$ sebagai berikut:

Antara 0,800 sampai dengan 1,000 : sangat tinggi : sangat tinggi

Antara 0,600 sampai dengan 0,799 : Tinggi

Antara 0,400 sampai dengan 0,599 : cukup tinggi

Antara 0,200 sampai dengan 0,399 : rendah

Antara 0,000 sampai dengan 0,199: sangat rendah. Arikunto, (2006: 170)

\section{HASIL PENELITIAN DAN PEMBAHASAN}

Hasil

Berdasarkan uraian yang telah dikumpulkan sebelumnya maka bab ini akan dilakukan analisa pembahasan yang diperoleh dalam penelitian ini. Hasil penelitian akan digambarkan sesuai dengan tujuan dan hipotesis yang diajukan sebelumnya.

Dari indikator menguasai materi pelajaran secara mendalam tersebut dapat dijelaskan bahwa dari 4 pertanyaan dengan jumlah keseluruhan 248.47 dengan rata-rata 62.12 memiliki kategori baik. 


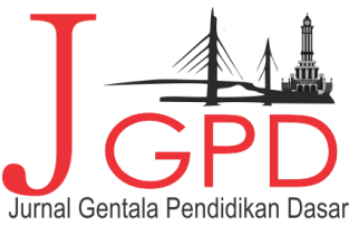

JURNAL geNTALA PENDIDIKAN DASAR Vol.3 o. I June 20I8 Page 92-1I0

P-ISSN : 2614-7092, E-ISSN : 262I-S6II

Available Dnline at: http://online-journal.unja.ac.id/index.php/gentala email : penyunting.jurnal.g-pgsd@unja.ac.id

Dari indikator Mempunyai wawasan luas dapat dijelaskan bahwa dari 3 pertanyaan dengan jumlah keseluruhan 189.49 dengan rata-rata 63.16 memiliki kategori baik.

Dari indikator komunikatif dapat dijelaskan bahwa dari 3 pertanyaan dengan jumlah keseluruhan 195.61 dengan rata-rata 65.20 memiliki kategori baik.

Dari indikator Mempunyai variasi pendekatan dapat dijelaskan bahwa dari 4 pertanyaan dengan jumlah keseluruhan 262.03 dengan rata-rata 65.51 memiliki kategori baik.

Data gaya mengajar guru dengan jumlah sampel 59 orang kemudian didapatkan jumlah nilai 6570 dengan rata-rata nilai 111,36, dan standar deviasi 10,11, nilai tertinggi yang didapatkan 141 dan terendah 89. Untuk data keaktifan belajar siswa dengan jumlah sampel 59 orang kemudian didapatkan jumlah nilai 3708 , dengan rata-rata nilai 62,85 , dan standar deviasi 7,13, nilai tertinggi yang didapatkan 79 dan terendah 42 .

Sebelum dilakukan uji hipotesis untuk melihat kontribusi dari variabel maka harus dilakukan terlebih dahulu uji normalitas kedua data tersebut maka uji normalitas data dapat digambarkan sebagai berikut:

\section{Uji Normalitas}

Untuk uji normalitas $\mathrm{L}_{\mathrm{O}}<\mathrm{L}_{\text {tabel}}$, maka data dari kedua variable memiliki distribusi data yang normal karena, untuk data gaya mengajar guru $\mathrm{L}_{\mathrm{O}}(0.0903)<$ Ltabel $(0,1153)$, sedangkan data keaktifan belajar siswa didapat Lo $(0,1014)<$ Ltabel $(0,1153)$.

Tabel 6. Uji Normalitas

\begin{tabular}{lllcl}
\hline Data & N & Lo & Ltabel & Keterangan \\
\hline Gaya Mengajar Guru & 59 & 0.0903 & 0,1153 & Normal \\
\hline Keaktifan Belajar Siswa & 59 & 0.1014 & 0,1153 & Normal \\
\hline
\end{tabular}

\section{Uji Homogenitas}

Uji homogenitas varians yang digunakan adalah Uji $\mathrm{F}$ dikatakan homogen apabila $\mathrm{F}$ hitung < F tabel, berdasarkan analisis data diperoleh $\mathrm{F}$ hitung $(2.006)<\mathrm{F}$ tabel $(3,15)$ maka berdasarkan hasil analisis dapat disimpulkan bahwa data bervariansi homogen. Untuk lebih jelasnya perhatikan tabel berikut : 
Tabel 7. Hasil Analisis Uji F

\begin{tabular}{cccc}
\hline $\begin{array}{c}\text { Sumber } \\
\text { variansi }\end{array}$ & F Hitung & F Tabel & Kriteria \\
\hline $\begin{array}{l}\text { Variabel } \\
\text { X dan Y }\end{array}$ & 2.006 & 3,15 & Homogen \\
\hline
\end{tabular}

Untuk uji hipotesis, melihat hubungan dari variable $\mathrm{X}$ dengan variabel $\mathrm{Y}$ maka dapat didiskripsikan sebagai berikut :

\begin{tabular}{llllll}
\hline $\mathrm{N}$ & $\mathrm{X}$ & $\mathrm{Y}$ & $\mathrm{X}^{2}$ & $\mathrm{Y}^{2}$ & $\mathrm{XY}$ \\
\hline 59 & 6570 & 3708 & 737532 & 235990 & 416371
\end{tabular}

\section{Pembahasan}

Di dalam kegiatan belajar diperlukan keterlibatan fisik maupun mental, sebagai suatu wujud reaksi. Belajar harus aktif, tidak sekedar apa adanya, menyerah pada lingkungan, tetapi semua itu harus dipandang sebagai tantangan yang memerlukan reaksi. Jadi orang yang belajar itu harus aktif, bertindak dan melakukannya dengan segala pancainderanya secara optimal. Belajar membutuhkan reaksi yang melibatkan ketangkasan mental, kewaspadaan, perhitungan, ketekunan, dan kecermatan untuk menangkap fakta-fakta dan ide-ide sebagaimana yang disampaikan oleh pengajarnya.

Proses belajar mengajar di sekolah, untuk melibatkan siswa aktif dalam belajarnya, maka guru juga dituntut untuk aktif dalam mengajarnya, yakni suatu keseimbangan antara keaktifan belajarnya siswa dan keaktifan mengajarnya guru. Oleh karena itu proses pembelajaran merupakan suatu kegiatan yang integral antara siswa sebagi pelajar dan guru sebagai pengajar. Dalam kegiatan ini terjadi interaksi antara guru dengan siswa dalam situasi pembelajaran, dimana proses belajar merupakan suatu aktivitas yang dijalankan oleh peserta didik, sedangkan proses mengajar ialah apa yang diusahakan oleh guru agar proses belajar mengajar dapat berlangsung.

Dari indikator menguasai materi pelajaran secara mendalam tersebut dapat dijelaskan bahwa dari 4 pertanyaan dengan jumlah keseluruhan 248.47 dengan rata-rata 62.12 memiliki kategori baik. Dari indikator Mempunyai wawasan luas dapat dijelaskan bahwa dari 3 pertanyaan dengan jumlah keseluruhan 189.49 dengan rata-rata 63.16 memiliki kategori baik, 


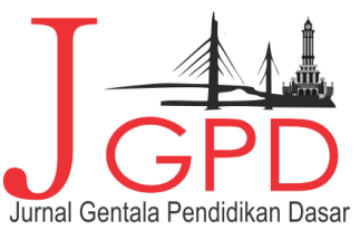

JURNAL gENTALA PENDIDIKAN DASAR Vol.3 No. I June 2018 Page 92-IID

P-ISSN : 2614-7092, E-ISSN : 2621-96il

Available Online at: http://online-journal.unja.ac.id/index.php/gentala email : penyunting.jurnal.g-pgsd逐unja.ac.id

indikator komunikatif dapat dijelaskan bahwa dari 3 pertanyaan dengan jumlah keseluruhan 195.61 dengan rata-rata 65.20 memiliki kategori baik, dari indikator Mempunyai variasi pendekatan dapat dijelaskan bahwa dari 4 pertanyaan dengan jumlah keseluruhan 262.03 dengan rata-rata 65.51 memiliki kategori baik.

Dari indikator tidak terlalau menekan dan memaksa dapat dijelaskan bahwa dari 1 pertanyaan dengan jumlah keseluruhan 73.56 dengan rata-rata 73.56 memiliki kategori baik, dari indikator tidak terlalau menekan dan memaksa dapat dijelaskan bahwa dari 6 pertanyaan dengan jumlah keseluruhan 379.32 dengan rata-rata 63.22 memiliki kategori baik, dari indikator duduk diatas meja ketika mengajar dapat dijelaskan bahwa dari 6 pertanyaan dengan jumlah keseluruhan 246.78 dengan rata-rata 61.69 memiliki kategori baik, dari indikator duduk diatas meja ketika mengajar dapat dijelaskan bahwa dari 2 pertanyaan dengan jumlah keseluruhan 120.68 dengan rata-rata 60.34 memiliki kategori baik, dari indikator Sering bolos mengajar dapat dijelaskan bahwa dari 2 pertanyaan dengan jumlah keseluruhan 126.44 dengan rata-rata 63.22 memiliki kategori baik, dari indikator Tidak disiplin dapat dijelaskan bahwa dari 2 pertanyaan dengan jumlah keseluruhan 126.44 dengan rata-rata 63.22 memiliki kategori baik. Dari indikator Tidak disiplin dapat dijelaskan bahwa dari 2 pertanyaan dengan jumlah keseluruhan 132.20 dengan rata-rata 66.10 memiliki kategori baik, dari indikator rasa ingin tahu yang tinggi dapat dijelaskan bahwa dari 4 pertanyaan dengan jumlah keseluruhan 247.80 dengan rata-rata 61.95 memiliki kategori baik, dari indikator pantang menyerah dapat dijelaskan bahwa dari 2 pertanyaan dengan jumlah keseluruhan 136.27 dengan rata-rata 68.14 memiliki kategori baik, dari indikator berani mengambil resiko dapat dijelaskan bahwa dari 2 pertanyaan dengan jumlah keseluruhan 118.98 dengan rata-rata 59.49 memiliki kategori cukup, dari indikator ingin mencari pengalaman-pengalaman baru dapat dijelaskan bahwa dari 4 pertanyaan dengan jumlah keseluruhan 247.12 dengan rata-rata 61.78 memiliki kategori baik, dari indikator optimis dapat dijelaskan bahwa dari 4 pertanyaan dengan jumlah keseluruhan 252.88 dengan rata-rata 63.22 memiliki kategori baik.

Dari indikator optimis dapat dijelaskan bahwa dari 4 pertanyaan dengan jumlah keseluruhan 253.90 dengan rata-rata 63.47 memiliki kategori baik, untuk data gaya mengajar guru dengan jumlah sampel 59 orang kemudian didapatkan jumlah nilai 6570 dengan ratarata nilai 111,36, dan standar deviasi 10,11, nilai tertinggi yang didapatkan 141 dan terendah 


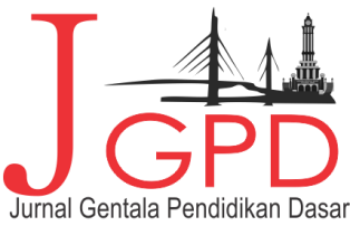

JURNAL gENTALA PENDIDIKAN DASAR Vol.3 o. I June 20I8 Page 92-1I0

P-ISSN : 2614-7092, E-ISSN : 262I-9611

Available Dnline at: http://online-journal.unja.ac.id/index.php/gentala

email : penyunting.jurnal.g-pgsd@unja.ac.id

89. Untuk data keaktifan belajar siswa dengan jumlah sampel 59 orang kemudian didapatkan jumlah nilai 3708 , dengan rata-rata nilai 62,85 , dan standar deviasi 7,13 , nilai tertinggi yang didapatkan 79 dan terendah 42 ,

Sebelum dilakukan uji hipotesis untuk melihat kontribusi dari variabel maka harus dilakukan terlebih dahulu uji normalitas kedua data tersebut. Untuk uji normalitas Lo < Ltabel, maka data dari kedua variabel memiliki distribusi data yang normal karena, untuk data gaya mengajar guru Lo (0.0903) < Ltabel $(0,1153)$, sedangkan data keaktifan belajar siswa didapat Lo $(0,1014)<$ Ltabel $(0,1153)$.

Dengan menggunakan rumus $(\mathrm{n}-2) 59-2=57$ pada $\alpha=0,05$, maka dengan $\mathrm{dk} 2$, untuk uji dua pihak t $0,95=1,6720$ mudah dilihat bahwa 11.15883>1,6720 maka terdapat hubungan gaya mengajar guru dengan keaktifan belajar siswa kelas V SD N 51/IV Kota Jambi.

\section{KESIMPULAN DAN IMPLIKASI}

\section{Kesimpulan}

Berdasarkan hasil penelitian maka dapat disimpulkan bahwa terdapat hubungan gaya mengajar guru dengan keaktifan belajar siswa kelas V SD N 51/IV Kota Jambi dengan hasil uji hipotesis yang signifikan dengan nilai korelasi Rxy 0.8282 dengan interpresyasi 0.800 sampai dengan 1.000 dengan kategori sangat baik.

1. Kualitas gaya mengajar guru di kelas V SD Negeri 51/IV Kota Jambi berjumlah 64.28 dengan kriteria Baik.

2. Kualitas keaktifan belajar siswa di kelas V SD Negeri 51/IV Kota Jambi berjumlah 63 dengan kriteria Baik.

\section{Implikasi}

1. Kualitas gaya mengajar guru hendaknya lebih beragam untuk menghindari kebosanan pada siswa

2. Kualitas keaktifan siswa agar selalu dipertahankan serta belajar kelompok dan diskusi hendaknya lebih sering dilakukan agar siswa lebih aktif

3. Tidak semua siswa mampu aktif, sehingga peran guru untuk melakukan pendekatan kepada setiap siswa sangat diperlukan. 


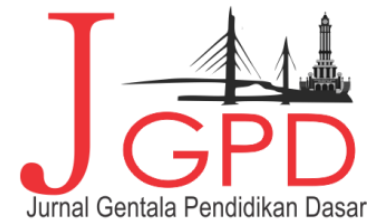

JURNAL gENTALA PENDIDIKAN DASAR Vol.3 o. I June 2018 Page 92-1I0

P-ISSN : 2614-7092, E-ISSN : 262I-S6II

Available Dnline at: http://online-journal.unja.ac.id/index.php/gentala email : penyunting.jurnal.g-pgsd国unja.ac.id

\section{UCAPAN TERIMAKASIH}

Dalam kesempatan ini disampaikan penghargaan dan rasa terima kasih yang setulustulusnya kepada keluarga besar SD N 51/IV Kota Jambi yang telah memfasilitasi kegiatan penelitian. Selanjutnya ucapan terimakasih kepada Bapak/Ibu pengelola Jurnal Gentala Pendidikan Dasar PGSD FKIP Universitas Jambi atas kerjasamanya sehingga karya ilmiah ini dapat diterbitkan.

\section{DAFTAR PUSTAKA}

Chabib. Thoha, 2006. Kapita Selekta Pendidikan. Yogyakarta: Pustaka Pelajar. Iskandar. 2008 Metodologi penelitian Pendidikan Sosial. Jakarta: Gaung Persada Pers. Jamal Ma'mur Asmani. 2009. Tips Pintar PTK: Penelitian Tindakan Kelas. Yogyakarta: Laksana.

Moedjiono dan Dimiyati. 2006. Belajar dan Pembelajaran. Bandung: Rineka Cipta.

M. Saputra Yudaha \& Husdarta. 2000. Belajar dan Pembeajaran. Depdiknas Direktorat Jendral Pendidikan Dasar dan Menengah Bagian Proyek Penataran Guru SLTP Setara D-III.

Mulyasa. 2002. Kurikulum Berbasis Kompetensi : Konsep, Karakteristik, dan Implementasi. Bandung : Remaja Rosdakarya.

Wanwan Setiawan. 2009. Pembelajaran Aktif, Kreatif, Efektif dan Menyenangkan untuk Guru SD. Bandung : Pusat Pengembangan dan Pemberdayaan Pendidik dan Tenaga Kependidikan Ilmu Pengetahuan Alam (PPPPTK IPA).

Munandar. 2009. Pengantar Ilmu Pendidikan. Semarang: UNNES Press.

Muhtadi, 2002. Menciptakan Iklim Kelas (Classroom Climate) Yang Kondusif Dan Berkualitas Dalam Proses Pembelajaran. Jurnal. Diakses tangaal 21 April 2015. $\mathrm{http} / /$ kemandirianbelajar_pengertian dalambelajar.//co/

Hamalik Oemar. 2002. Media Pendidikan. Bandung: Citra Aditya Bakti.

Suharsimi Arikunto. 2006. Penelitian Tin dakan Kelas. Jakarta: Bumi Aksara.

Syaiful Bahri Djamarah. 2010. Strategi Belajar Mengajar. Jakarta: Rineka Cipta.

Sudjana, N. 2000. Penilaian Hasil Proses Belajar Mengajar. Bandung: PT.Pekerja Rosdakarya.

Sudjana, N. 2004. Penilaian Hasil Proses Belajar Mengajar. Bandung: PT.Pekerja Rosdakarya.

Supriyono, 2004. Belajar dan pembelajaran. Gramedia Pustaka. Jakarta

Sugandi, Achmad. 2007. Teori Pembelajaran. Semarang: UNNES Press.

Suryosubroto. 2002. Proses Belajar Mengajar di Sekolah. Jakarta: Rineka Cipta.

Sugiyono. 2009. Metode Penelitian Pendidikan. Jakarta: P.T Raja Grafindo Persada

Suprihatiningrum, Jamil. 2013. Guru Profesional. Jogjakarta: Ar-ruzz Media

Sardiman, A. 2006. Media Pembelajaran. Jakarta: Rajawali Pers.

Usman, Moh. Uzer. 2009. Menjadi Guru Profesional. Bandung: Remaja Rosdakarya. 